International Research Journal of Engineering, IT \& Scientific Research
Available online at https://sloap.org/journals/index.php/irjeis/
Vol. 7 No. 1, January 2021, pages: 25-32
ISSN: 2454-2261
https://doi.org/10.21744/irjeis.v7n1.1225

\title{
Isolated Photovoltaic System for House: Pre-sizing
}

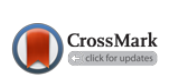

\author{
Jessica Katherine Moreira Veliz ${ }^{\text {a }}$ \\ Juan Francisco Velepucha Gualán ${ }^{\text {b }}$ \\ Felipe Alejandro León Mateo ${ }^{c}$ \\ Andy Ariel Guerrero Veléz d \\ María Rodríguez Gámez ${ }^{\mathrm{e}}$
}

Article history:

Submitted: 09 November 2020

Revised: 18 December 2020

Accepted: 27 January 2021

\section{Keywords:}

electricity;

isolated generation;

photovoltaic systems;

renewable energy;

solar potential;

\section{Corresponding author:}

Jessica Katherine Moreira Veliz,

Student of the Electrical Engineering career

Universidad técnica de Manabí, Portoviejo, Ecuador.

Email address: jmoreira2386@utm.edu.ec

\begin{abstract}
Photovoltaic solar energy is a clean renewable energy source that allows obtaining electricity directly from solar radiation through semiconductor devices called photovoltaic cells. The present research aims to pre-design an isolated system for a house that can serve as a pattern for the electrification of houses that today do not have power in the province of Manabí. To carry out the proposal, the PVsyst was used, a tool for sizing the system, in addition to the bibliographic review, the qualitative-quantitative, and the inductive deductive. It was obtained as a result that photovoltaic solar energy is adequate to provide a solution to isolated homes that today do not have energy service, in addition to those that have a poor quality of service.
\end{abstract}

International research journal of engineering, IT \& scientific research (C) 2021. This is an open access article under the CC BY-NC-ND license (https://creativecommons.org/licenses/by-nc-nd/4.0/).

a Student of the Electrical Engineering career, Universidad Técnica de Manabí, Portoviejo, Ecuador

b Student of the Electrical Engineering career, Universidad Técnica de Manabí, Portoviejo, Ecuador

${ }^{c}$ Professor of the Electrical Engineering career, Universidad Técnica de Manabí, Portoviejo, Ecuador

${ }^{\text {d }}$ Student of the Electrical Engineering career, Universidad Técnica de Manabí, Portoviejo, Ecuador

e $\mathrm{PhD}$. Universidad Técnica de Manabí, Portoviejo, Ecuador 


\section{Introduction}

Solar energy is a type of renewable energy, it is obtained by electromagnetic radiation from the Sun that falls on the earth's surface (Zou et al., 2017; El-Ghonemy, 2012; Dincer, 2000). The solar radiation that reaches the earth has been used by humans using various technologies developed since ancient times. Today, the heat and light from the sun can be used by various collectors, such as photovoltaic cells, heliostats, or solar collectors, and can be converted into electrical or thermal energy (Castro \& Colmenar, 2019). It is one of the so-called renewable energies or clean energies, which could help solve some of the current most urgent problems that living beings face (Gámez et al., 2018).

The power of radiation depends on the time of day, the attenuating atmospheric conditions are radiation and latitude. Under acceptable radiation conditions, the power at the earth's surface is approximately $1000 \mathrm{~W} / \mathrm{m}^{2}$. This capacity is called irradiance (Hernández et al., 2014). With the help of solar panels, the operation of photovoltaic systems becomes possible. In solar panels, solar energy is converted into direct current by the photoelectric effect, if it is not converted into alternating current it cannot be used conventionally (Joerissen et al., 2004; Fabjan et al., 2001). This is where the inverter function comes into play and it is a key part of the photovoltaic system because it is he who converts the current so that it is compatible with any type of equipment, such as the home, business, or industry. Then, depending on the type of photovoltaic system, it can have a charge controller that regulates energy use and a battery pack that allows energy storage (Loor et al., 2020).

In the province of Manabí, there is enough solar potential to implement the technology in isolated and difficultto-access areas (Vázquez et al., 2018; Hachem et al., 2011; Lukač et al., 2013), different studies have been carried out that demonstrate the high existing potential that can be used for different uses (Rodríguez \& Vázquez, 2018). One of the alternatives that can be used is distributed generation connected to the load to reduce demand during daytime hours (Guerrero et al., 2020), in the mode of distributed generation through microgrids trying to complete the strategy of changing the energy matrix by varying the different potentials (Saltos et al., 2017). Solar energy combined with other renewable potentials can provide a solution to many electrification problems in the province of Manabí, mainly for isolated homes so that energy sustainability can be achieved in areas that today do not have energy service (Vázquezet al., 2020).

\section{Materials and Methods}

For the development of the article, the literature review, the PVsyst software (PVsyst, 2020), was used as a methodology for the pre-dimensioning, in addition to a qualitative and quantitative method to be able to assess the results obtained in the software. The inductive-deductive to deduce the possibility of offering energy to isolated homes in the province of Manabí.

\section{Results and Discussions}

Using the free version of the PVsyst, it was possible to perform the pre-dimensioning of the system starting from the Open Site option, where a tab is opened in which the place, country, and region in which to go must be selected. To carry out the study, selecting, in this case, we started from Ecuador - Portoviejo - South America, when choosing the aforementioned options, the geographical coordinates of the selected place will appear, also, the name of the project in which it was located Pre-dimensioned was incorporated isolated system in Portoviejo, as shown in figure 1. 


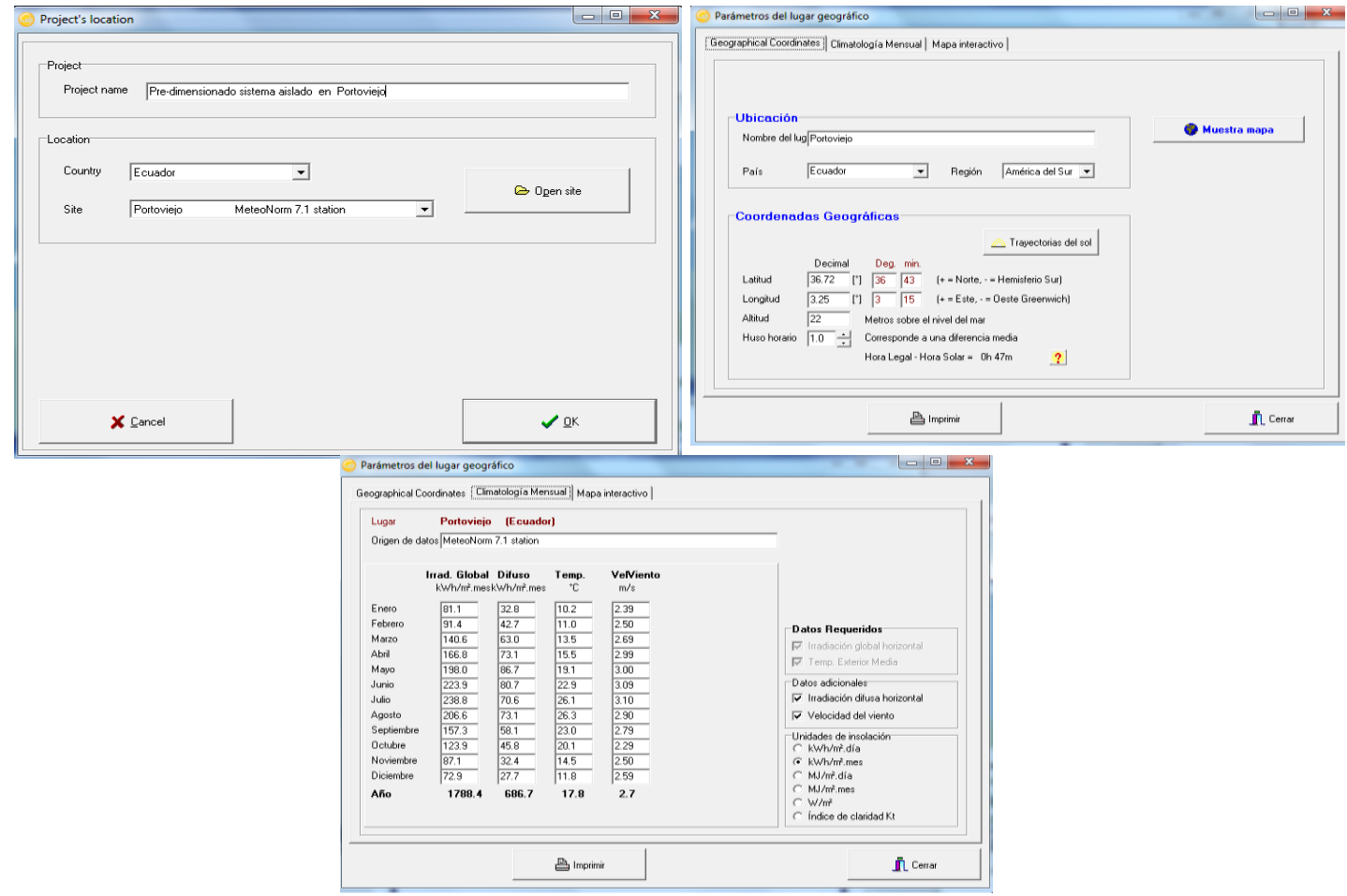

Figure 1. Climatological data of the study site Source: (PVsyst, 2020)

In the upper part of the Monthly Climatology option, the software through the NASA page (NASA, 2020), offers the irradiation values of the selected place. In the main window, click on the option user needs where the installed loads will appear and proceed to define them as shown in figure 2.

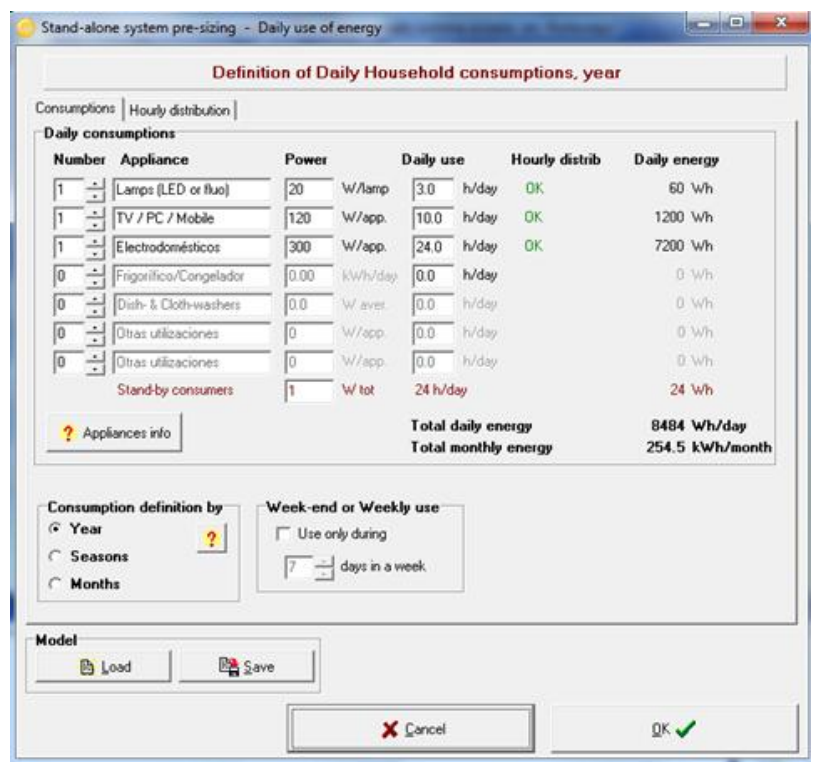

Figure 2. Definition of installed loads Source: (PVsyst, 2020)

Veliz, J. K. M., Gualán, J. F. V., Mateo, F. A. L., Veléz, A. A. G., \& Gámez, M. R. (2021). Isolated photovoltaic system for house: pre-sizing. International Research Journal of Engineering, IT \& Scientific Research, 7(1), 25-32. https://doi.org/10.21744/irjeis.v7n1.1225 
Once loads of the house have been placed, the hours of consumption are defined. In this way, a graph will be obtained that represents the load profile of the day, as shown in figure 3.

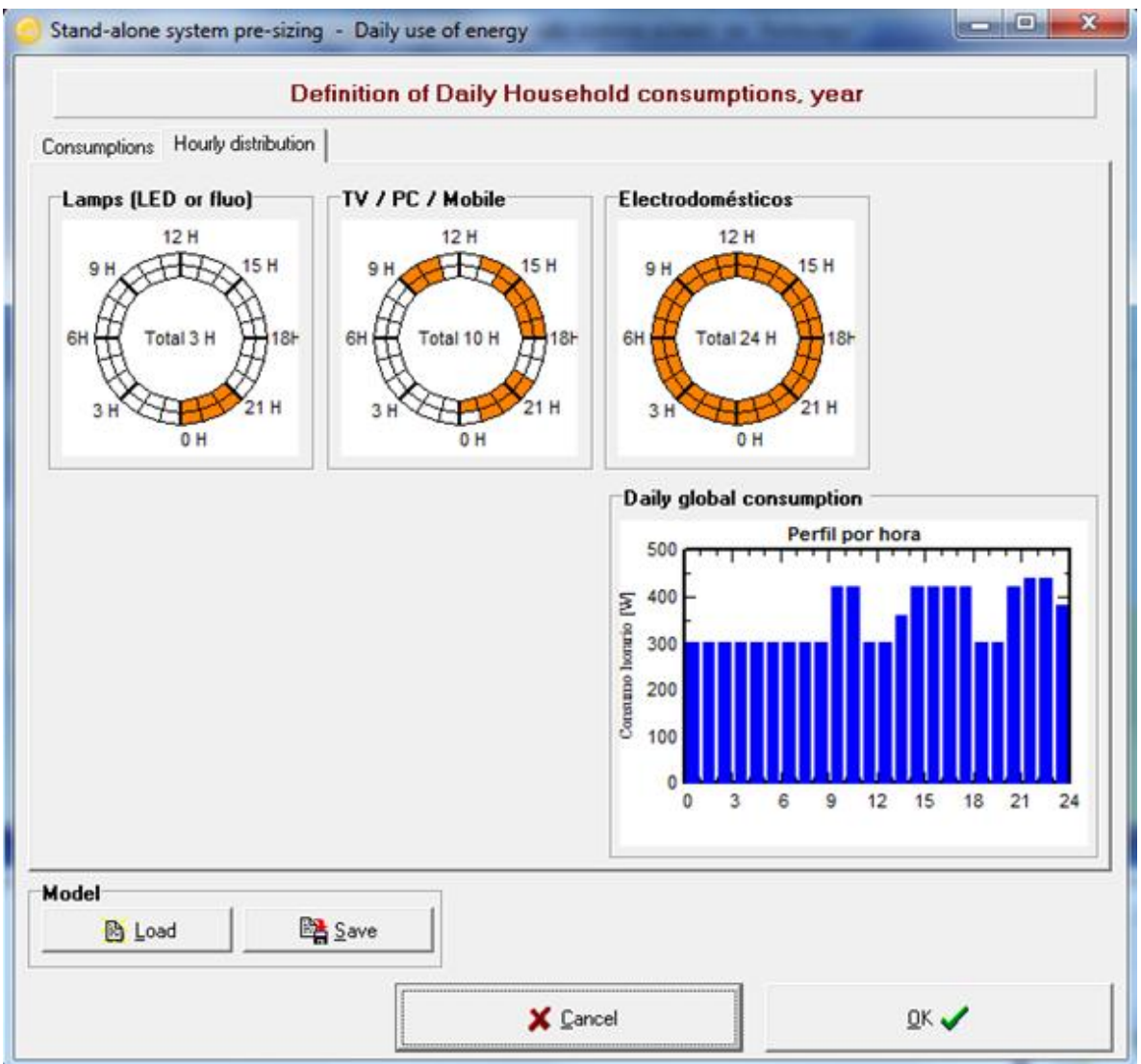

Figure 3. Load profiles of the day Source: (PVsyst, 2020)

The inclination of the solar panels is defined by clicking on the System option, and the window that appears where you can select the angle of inclination in the case of Portoviejo, you can select between 10 and 5 degrees, which are the ones that allow greater generation. Finally, the isolated system was simulated by clicking on results, where the days of autonomy of the system were defined, in which 2 days were located and the depth of discharge of the battery of $10 \%$ and the voltage of $12 \mathrm{~V}$ As can be seen in figure 4, despite the simulation with a 21 -degree incline, the generation levels are above the users' needs, demonstrating that there is sufficient potential to achieve the electrification of isolated homes. 


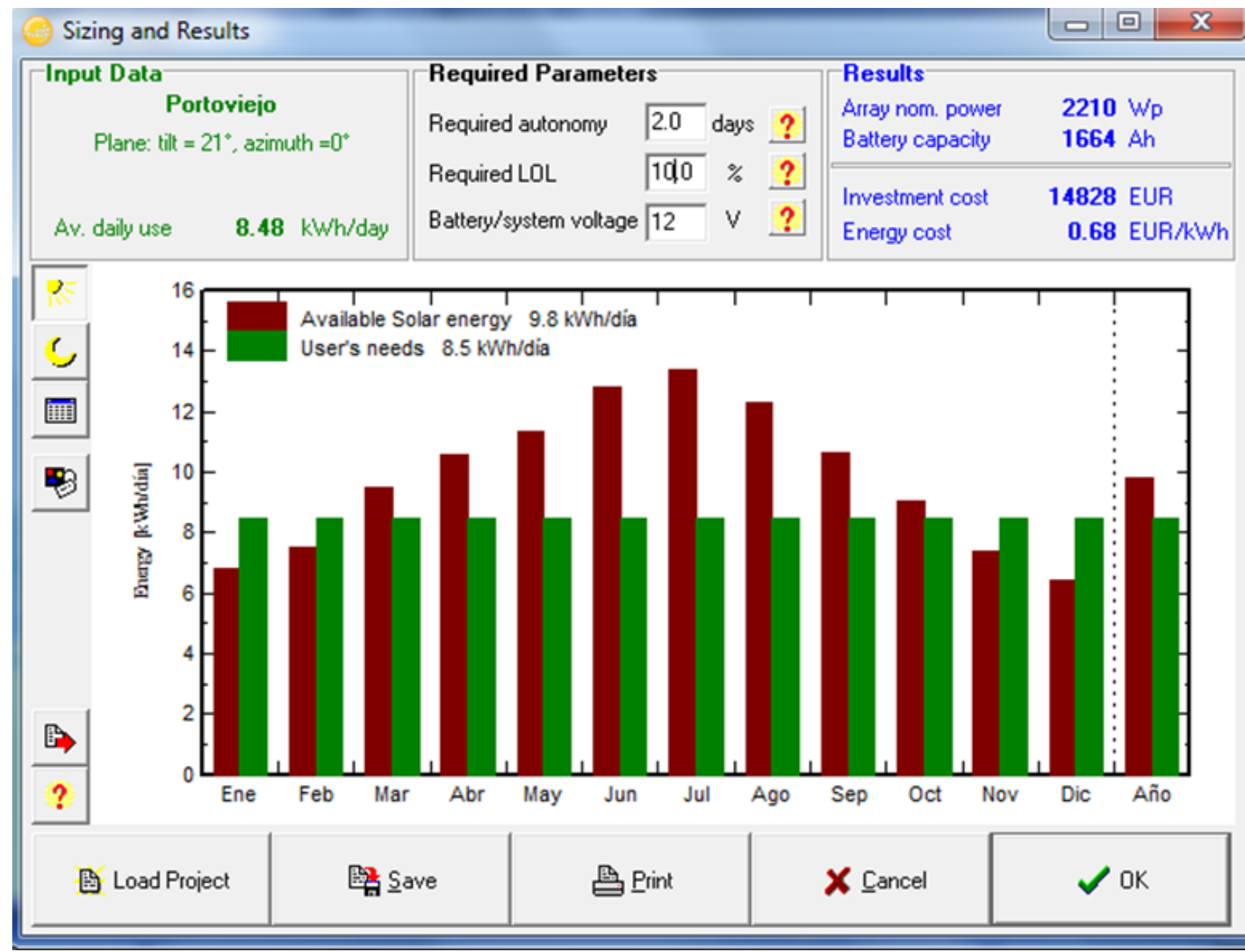

Figure 4. Available potential and housing needs Source: (PVsyst, 2020)

It was possible to obtain a report detailing the geographic location, the monthly climatic values, and the Solar trajectory in Portoviejo. Through the simulation, the final results were obtained, demonstrating that there is potential for the pre-dimensioning of isolated homes in the province of Manabí and with this, achieving electrification of the $5 \%$ of homes that today do not have electricity service or those that are considered to have a poor quality of energy (Gámez et al., 2018). Figure 5 shows the final report that is generated with the PVsyst software. As can be seen with the solar potential that exists, enough energy can be generated for isolated homes.

Veliz, J. K. M., Gualán, J. F. V., Mateo, F. A. L., Veléz, A. A. G., \& Gámez, M. R. (2021). Isolated photovoltaic system for house: pre-sizing. International Research Journal of Engineering, IT \& Scientific Research, 7(1), 25-32. https://doi.org/10.21744/irjeis.v7n1.1225 


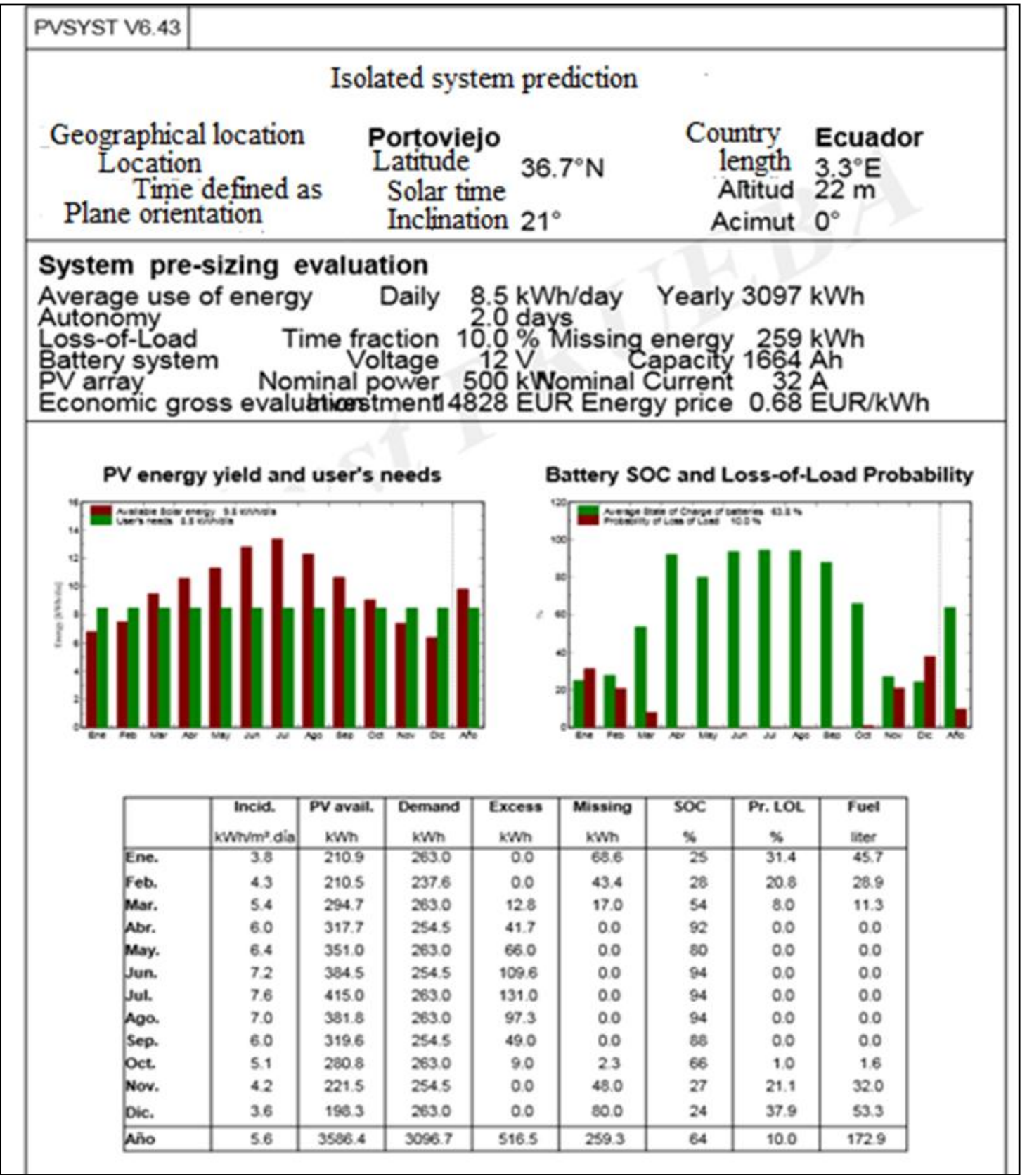

Figure 5. Final report

Source: (PVsyst, 2020)

It can be seen that the report shows all the information that was located in the study, it continues with the preselection evaluation system. Then it shows a first graph in which the energy performance and needs of the users are observed and a second graph of the average state of battery charge and the probability of loss of charge and finally a table with all the annual values of the complete study of the load. The results obtained from the pre-sizing of the photovoltaic system using the PVsyst software demonstrated the feasibility and benefits of the implementation of solar panels. Determining the variables that the system requested to acquire a general report of the system. Both photovoltaic energy and cogeneration are technically and economically viable options and are feasible in the current context, so prices continue to rise and the demand for electricity in low-energy buildings grows. 


\section{Conclusion}

Photovoltaic energy is a good alternative to traditional energy sources, since Portoviejo and the province of Manabí have a high potential for solar radiation, without the need to use traditional energy sources, they can also cause damage to the environment. Photovoltaic solar energy is clean, it is an inexhaustible source of energy and does not cause significant damage to the environment, it is also very useful in areas where it is difficult to connect to the grid, it is economically feasible, low maintenance, the system can provide energy for 20 years on average.

Conflict of interest statement

The authors declared that they have no competing interests.

\section{Statement of authorship}

The authors have a responsibility for the conception and design of the study. The authors have approved the final article.

Acknowledgments

We are grateful to two anonymous reviewers for their valuable comments on the earlier version of this paper.

Veliz, J. K. M., Gualán, J. F. V., Mateo, F. A. L., Veléz, A. A. G., \& Gámez, M. R. (2021). Isolated photovoltaic system for house: pre-sizing. International Research Journal of Engineering, IT \& Scientific Research,

7(1), 25-32. https://doi.org/10.21744/irjeis.v7n1.1225 


\section{References}

Castro, M., \& Colmenar, A. (2019). Estimation of global solar radiation, using extreme temperatures, applying the Bristow-Campbell model in the Junín region, Peru. I will engineer. Chilean Engineering Journal, 27(4).

Dincer, I. (2000). Renewable energy and sustainable development: a crucial review. Renewable and sustainable energy reviews, 4(2), 157-175. https://doi.org/10.1016/S1364-0321(99)00011-8

El-Ghonemy, A. M. K. (2012). Retracted: water desalination systems powered by renewable energy sources, Review. https://doi.org/10.1016/j.rser.2011.11.002

Fabjan, C., Garche, J., Harrer, B., Jörissen, L., Kolbeck, C., Philippi, F., ... \& Wagner, F. (2001). The vanadium redox-battery: an efficient storage unit for photovoltaic systems. Electrochimica Acta, 47(5), 825-831. https://doi.org/10.1016/S0013-4686(01)00763-0

Gámez, MR, Pérez, AV, Quiroz, AMV, \& Arauz, WMS (2018). Improvement of energy quality with photovoltaic systems in rural areas. Scientific Journal , 3 (33), 265-274.

Guerrero, J.X., Loor, A.K., Loor, G.A., Saltos, W.M., \& Cuenca, L.A. (2020). Load analysis to solve daytime demand in a house located in the "la armenia" urbanization with a sizing of photovoltaic cells connected to the grid. International Journal of Physical Sciences and Engineering, 4(3), 16-26.

Hachem, C., Athienitis, A., \& Fazio, P. (2011). Parametric investigation of geometric form effects on solar potential of housing units. Solar Energy, 85(9), 1864-1877. https://doi.org/10.1016/j.solener.2011.04.027

Hernández, J., Trujillo, C., \& Vallejo, A. (2014). Irradiation and ambient-temperature model using probability. Tecnura, 18(39), 128-137.

Joerissen, L., Garche, J., Fabjan, C., \& Tomazic, G. (2004). Possible use of vanadium redox-flow batteries for energy storage in small grids and stand-alone photovoltaic systems. Journal of power sources, 127(1-2), 98-104. https://doi.org/10.1016/j.jpowsour.2003.09.066

Loor, A.K., Guerrero, J.X., \& Calderón, G.I. (2020). Environmental Impact of Sustainable Housing in Rural Area of. International Journal of Life Sciences, 4(3), 31-40.

Lukač, N., Žlaus, D., Seme, S., Žalik, B., \& Štumberger, G. (2013). Rating of roofs' surfaces regarding their solar potential and suitability for PV systems, based on LiDAR data. Applied energy, 102, 803-812. https://doi.org/10.1016/j.apenergy.2012.08.042

Rodríguez, M., \& Vázquez, A. (2018). Photovoltaic Energy in the Province of Manabí. (EU-U. Universitaria, Ed.) Portoviejo.

Saltos, W.M., Rodríguez, M., Vázquez, A., Castro, M., \& Nieto, H. (2017). Geographic information systems and microgrids. Cuban Journal of Engineering, $\operatorname{VIII}(1), 24-29$.

Vázquez, A., Rodríguez, M., Saltos, W.M., Rodríguez, C., \& Cuenca, L.A. (2018). Energy, economic and environmental performance of a $3.4 \mathrm{KWp}$ Photovoltaic Power Plant in the distributed generation (GD) mode. Espacios, 39(47), 34.

Vázquez, A., Saltos, W.M., Villacreses, C.G., \& Rodríguez, M. (2020). A model for sustainable energy development. The university, geography and endogenous resources / A model for sustainable energy development. The university, geography. (E. d. Universidad de Los Andes, Ed.) Venezuelan Geographical Magazine, 61(1), 220-234.

Zou, L., Wang, L., Xia, L., Lin, A., Hu, B., \& Zhu, H. (2017). Prediction and comparison of solar radiation using improved empirical models and Adaptive Neuro-Fuzzy Inference Systems. Renewable energy, 106, 343-353. https://doi.org/10.1016/j.renene.2017.01.042 